OPEN ACCESS

ISSN 2548-3501 (online)

Edited by:

Abdurrahman Maulana Yusuf

${ }^{*}$ Correspondence:

Elliv Hidayatul Lailiyah

ellivhidayatullailiyah@gmail.com

Received: 13 December 2021

Accepted: 26 January 2022

Published: 31 January 2022

Citation:

Lailiyah, Dewi dan Lestari (2022)

Literasi Keuangan sebagai

Variabel moderasi pada

Organisasi Keagamaan

Muhammadiyah di Indonesia

\section{Prediksi Financial Behaviour Dengan Literasi Keuangan sebagai Variabel Moderasi pada Organisasi Keagamaan Muhammadiyah di Indonesia}

\author{
Elliv Hidayatul Lailiyah*, Arfiana Dewi, Yahya Shidiq, Dian Lestari \\ Institut Teknologi dan Bisnis Ahmad Dahlan Lamongan, Indonesia
}

The purpose of this study is to determine the prediction of Financial Behavior and to determine the role of financial literacy moderation in Muhammadiyah Organizations in Indonesia. This study tested 102 members of the organization using Convenience sampling method, data analysis using Moderated Regression Analysis (MRA). The results showed that Locus of Control, Financial Attitude, Income, and Religiosity succeeded in predicting Financial Behavior and financial literacy managed to moderate the effect on these variables. The results of the study have implications that members of the Muhammadiyah organization in Indonesia have good financial behavior based on the research variables used in this study.

\begin{abstract}
Keywords: financial behaviour, Locus of control, Income, religiosity, Financial Literacy
Tujuan penelitian ini yaitu untuk mengetahui prediksi Financial Behaviour dan mengetahui peran moderasi literasi keuangan pada Organisasi Keagamaan Muhammadiyah di Indonesia. Penelitian ini menguji 102 anggota organisasi dengan menggunakan metode Convenience sampling, analisis data menggunakan Moderated Regression Analysis (MRA). Hasil penelitian menunjukkan bahwa Locus of Control, Sikap Keuangan, Pendapatan, dan Religiusitas berhasil memrediksi Financial Behaviour dan literasi keuangan berhasil memoderasi pengaruh pada variabel tersebut. Hasil penelitian berimplikasi bahwa anggota organisasi Muhammadiyah di Indonesia telah memiliki financial behaviour yang baik berdasarkan variabel penelitian yang digunakan pada penelitian ini.
\end{abstract}

Keywords: financial behaviour, Locus of control, pendapatan, religiositas, literasi keuangan 


\section{PENDAHULUAN}

Permasalahan ekonomi yang semakin kompleks membuat manusia dituntut untuk terus berusaha mencari solusi dalam memenuhi kebutuhan. Saat ini, masyarakat modern sering dihadapkan dengan masalah keuangan. Evolusi ekonomi digital saat ini membuat semakin mudah mengakses berbagai informasi. Penyebaran informasi juga semakin cepat sehingga keinginan masyarakat akan semakin tinggi dan perilaku konsumtif tidak dapat dihindari. Hal tersebut juga didukung oleh ekonomi keuangan kelas menengah ke atas. Masyarakat yang berpenghasilan cukup besar mungkin tidak dapat mengelola pengeluaran keuangannya dengan baik, hal ini terjadi karena perilaku ekonomi yang tidak bertanggung jawab dan adanya praktik belanja yang impulsi (Haerani et al., 2019; Bulutoding et al., 2020; Mokhtar et al., 2020; Sudarsono et al., 2020).

Gaya hidup mewah mendorong kebutuhan dan keinginan lebih lanjut, sehingga menyebabkan individu dengan pendapatan yang cukup besar mengalami masalah keuangan (Lusardi et al., 2010; Meghir \& Pistaferri, 2011; Parmitasari, Alwi, \& Sunarti, 2018). Atas dasar itu, seorang individu modern harus memiliki pengetahuan dalam mengelola keuangan secara bijak. Selain itu, Jumlah produk keuangan yang semakin canggih terus meningkat saat ini. Sehingga, untuk dapat menggunakan produk yang canggih secara rasional, individu perlu memiliki pemahaman finansial tertentu (Grohman, 2018).

Pandemi COVID-19 memberikan dampak yang luar biasa terhadap segala aspek kehidupan. Salah satunya terhadap kondisi keuangan setiap individu. Kholid et al. (2020) menjelaskan bahwa perilaku keuangan Indonesia cenderung konsumtif, mengarah pada berbagai perilaku keuangan yang tidak bertanggung jawab seperti kurangnya tabungan, investasi, perencanaan dana darurat, dan penganggaran masa depan. Financial Behaviour merupakan studi tentang bagaimana manusia berperilaku dalam masalah keuangan, khususnya bagaimana proses pengambilan keputusan berlangsung terkait dengan keputusan keuangan (Nofsinger, 2001; Ricciardi, 2008; Nofsinger \& Varma, 2014).

Adanya pandemi COVID-19 memperparah dampak perilaku keuangan Indonesia tersebut. Penurunan konsumsi dan daya beli masyarakat serta turunnya kinerja perusahaan merupakan akibat dari pandemi COVID-19 (Saraswati dan Nugroho, 2021). Hal tersebut memengaruhi pengelolaan keuangan masyarakat sehingga masyarakat perlu mengetahui literasi keuangan lebih baik lagi. Masyarakat yang tidak memiliki literasi keuangan yang baik akan mengalami masalah keuangan yang lebih komplek. Literasi keuangan merupakan pengetahuan, keterampilan dan keyakinan yang mempengaruhi sikap dan perilaku untuk meningkatkan kualitas pengambilan keputusan dan pengelolaan keuangan dalam rangka mencapai kesejahteraan (OJK, 2020).

Berdasarkan survei nasional literasi dan inklusi keuangan yang dilakukan oleh Otoritas Jasa Keuangan tahun 2019 memperlihatkan bahwa literasi keuangan di Indonesia masih mencapai 38,03 \%. Artinya, literasi keuangan di Indonesia berada pada level menengah. Literasi keuangan yang dimiliki seorang individu dengan baik akan mempengaruhi perilaku keuangan individu tersebut yaitu mampu mengelola keuangan dengan baik. Sehingga individu yang memiliki literasi keuangan yang baik akan membuat dampak positif pada perilaku keuangannya. Berbeda dengan seseorang yang memiliki literasi keuangan yang kurang baik, individu tersebut cenderung akan gagal dalam mengelola keuangan dan berakibat pada kesejahteraan keuangannya.

Organisasi Islam di Indonesia memberikan pengaruh yang sangat besar dan sangat penting dalam kehidupan individu. Salah satu dari top two organisasi Islam terbesar di Indonesia yang memiliki pengaruh sangat kuat adalah organisasi Muhammadiyah. Berdasarkan survei dari Alvara Research Center tahun 2017 menyimpulkan bahwa Organisasi Muhammadiyah memiliki citra sebagai ormas yang modernist dan contextualis. Berdasarkan hal tersebut penelitian ini memilih organisasi Muhammadiyah sebagai obyek penelitian. Citra modernist dan contextualis yang dimiliki organisasi Muhammadiyah, membuat anggota dari organisasi Muhammadiyah merupakan individu yang memahami tentang literasi keuangan dan perilaku keuangan.

Penelitian ini menggunakan variabel moderasi literasi keuangan untuk lebih menjelaskan terkait pengaruh sikap keuangan dan pendapatan terhadap financial behaviour. Variabel moderasi tersebut merupakan pembeda dari penelitian sebelumnya yaitu penelitian Abbas (2020). Anggota organisasi Muhammadiyah yang terliterasi dengan baik akan mendukung sikap yang positif terhadap uang, yang nantinya akan mempengaruhi perilaku keuangannya. Anggota organisasi Muhammadiyah yang memiliki literasi dengan baik, ketika memperoleh pendapatan akan menggunakan pendapatannya secara bijak, sehingga mencerminkan perilaku keuangan yang juga lebih bijak untuk kehidupan masa depannya. Penelitian ini berfokus pada saat masa Pandemi COVID-19 untuk memprediksi financial behaviour dengan literasi keuangan sebagai variabel moderasi khusunya pada organisasi keagamaan Muhammadiyah.

Terdapat beberapa faktor yang memengaruhi perilaku keuangan yaitu Locus of control, sikap keuangan, pendapatan, dan religiositas (Abbas et al.,2020). Rotter (1966) menyatakan bahwa locus of control adalah perspektif individu dalam melihat atau mengendalikan peristiwa yang terjadi padanya terhadap peristiwa tersebut. Locus of control dibagi dalam dua bentuk yaitu locus of control internal dan locus of control eksternal. Lefcourt (1982) menyatakan individu dengan locus of control internal meyakini bahwa keberhasilan atau kesuksesan dalam hidupnya berada dalam kontrol mereka. Sebaliknya, individu dengan locus of control eksternal meyakini bahwa keberhasilan atau kesuksesan dalam hidupnya di luar kontrol mereka. Penelitian ini loc diprediksi memengaruhi perilaku keuangan anggota organisasi Muhammadiyah, beberapa penelitian sebelumnya mendukung loc berpengaruh terhadap perilaku keuangan (Perry \& Morris, 2005; Ida \& Dwinta, 2010; Britt et al., 2013; Abbas et al., 2020).

Sikap merupakan perasaan mendukung (positif) atau tidak mendukung (negatif) berdasarkan evaluasi menyeluruh seseorang terhadap uang (sikap terhadap objek) (Ajzen,2005). Amanah et al. (2016) menjelaskan bahwa sikap keuangan merupakan kecenderungan psikologis yang diekspresikan ketika mengevaluasi praktik manajemen keuangan yang direkomendasikan dengan beberapa tingkatan kesepakatan dan ketidaksepakatan. Sikap keuangan memiliki implikasi penting dalam pengetahuan keuangan (Ameliawati dan Setiyani, 2018). Penelitian ini sikap keuangan diprediksi memengaruhi perilaku keuangan anggota organisasi Muhammadiyah. Penelitian ini mendukung penelitian sebelumnya tentang pengaruh sikap keuangan terhadap perilaku keuangan (Lai, 2010; Falahati, 2011; Ameliawati \& Setiyani, 2018; Yap et. al., 2018).

Individu yang terliterasi dengan baik akan mendukung 
sikap yang positif terhadap uang, yang nantinya akan mempengaruhi perilaku keuangannya. Seseorang yang memiliki tingkatan well literate akan lebih bijak dalam perilaku keuangannya. Individu dengan tingkat literasi yang baik akan dapat membedakan antara kebutuhan dan keinginan, sehingga sikap terhadap uang akan lebih positif yang tentunya akan berpengaruh terhadap perilaku keuangan yang positif. Penelitian ini literasi keuangan diprediksi memperkuat pengaruh sikap keuangan terhadap perilaku keuangan anggota organisasi Muhammadiyah.

Pendapatan merupakan sebuah hasil yang diperoleh dari jerih payah seseorang dalam bekerja dan dinilai dengan tingkat atau nilai tertentu. Pendapatan didapatkan dengan berbagai cara. Pendapatan juga digunakan untuk mempersiapkan dan memenuhi kebutuhan serta untuk keperluan mendesak atau dimasa yang akan datang. Pendapatan seseorang merupakan sumber informasi dan rangsangan esensial dalam melaksanakan berbagai kegiatan, terutama pengelolaan uang individu. Ketika pendapatan mengubah bagaimana individu membentuk perilaku keuangan (Perry \& Morris, 2005; Ida \& Dwinta, 2010; Delafrooz \& Paim, 2011;).

Individu yang terliterasi dengan baik, ketika memperoleh pendapatan akan menggunakan pendapatannya secara bijak. Individu tersebut tidak hanya menggunakannya untuk tujuan konsumsi tetapi juga menggunakan pendapatannya untuk investasi. Artinya ketika memperoleh pendapatan, maka individu tersebut akan memiliki tujuan keuangan yang lebih mementingkan tujuan jangka panjang dan masa depannya sehingga mencerminkan perilaku keuangan yang juga lebih bijak untuk kehidupan masa depannya. Variabel moderasi literasi keuangan merupakan pembeda dari penelitian sebelumnya yaitu penelitian Abbas (2020). Pada penelitian ini literasi keuangan diprediksi memperkuat pengaruh pendapatan terhadap perilaku keuangan anggota organisasi Muhammadiyah.

McDaniel dan Burnett (1990) mendefinisikan religiositas sebagai kepercayaan kepada Tuhan disertai dengan komitmen untuk mengikuti prinsip-prinsip yang telah ditetapkan oleh Tuhan. Weaver dan Agle (2002) menyatakan bahwa religiusitas memiliki pengaruh baik pada perilaku dan sikap manusia. Penelitian ini menggunakan sampel anggota keagamaan Muhammadiyah yang dalam kesehariannya akan mengedepankan nilai-nilai religiositas yang salah satunya dicerminkan pada perilaku keuangannya. Penelitian ini religiositas diprediksi memengaruhi perilaku keuangan anggota organisasi Muhammadiyah, beberapa penelitian sebelumnya mendukung religiositas berpengaruh terhadap perilaku keuangan (Hess, 2012; Renneboog \& Spaenjers, 2012; Ali, 2016).

Berdasarkan fenomena yang telah dijelaskan maka hipotesis dalam penelitian ini adalah

$\mathrm{H}_{1}$ : LOC berpengaruh positif terhadap financial behaviour pada Organisasi Keagamaan Muhammadiyah di Indonesia

$\mathrm{H}_{2 \mathrm{a}}$ : Sikap Keuangan berpengaruh positif terhadap financial behaviour pada Organisasi Keagamaan Muhammadiyah di Indonesia

$\mathrm{H}_{2 b}$ : Literasi Keuangan memperkuat pengaruh Sikap Keuangan terhadap financial behaviour pada Organisasi Keagamaan Muhammadiyah di Indonesia

$\mathrm{H}_{3 \mathrm{a}}$ : Pendapatan berpengaruh positif terhadap financial behaviour pada Organisasi Keagamaan Muhammadiyah di Indonesia
$\mathrm{H}_{3 \mathrm{~b}}$ : Literasi Keuangan memperkuat pengaruh Pendapatan terhadap financial behaviour pada Organisasi Keagamaan Muhammadiyah di Indonesia

$\mathrm{H}_{4}$ : Religiositas berpengaruh positif terhadap financial behaviour pada Organisasi Keagamaan Muhammadiyah di Indonesia

\section{METODE}

\section{Jenis Penelitian}

Jenis penelitian yang digunakan adalah penelitian kuantitatif. Penelitian kuantitatif merupakan penelitian yang berfokus pada pengujian hipotesis. Terdapat enam hipotesis yang diajukan dalam penelitian ini, hipotesis pada penelitian ini berisi empat variable independen, satu variable dependen, dan satu variable moderasi.

\section{Sumber Data Penelitian}

Pengumpulan data dalam penelitian ini adalah data primer berupa kuesioner. Kuesioner dikirim oleh peneliti ke grup whatsapp Muhammadiyah di Indonesia. Penyusunan kuesioner memanfaatkan google form untuk memudahkan pengumpulan data dan meminimalkan risiko pandemi COVID-19.

\section{Variabel Penelitian}

Variabel independen pada penelitian ini yaitu locus of control (loc), sikap keuangan, pendapatan, dan religiusitas. Pengukuran pertanyaan variabel independen tersebut menggunakan Skala Likert 5 poin, poin 1 menyatakan sangat tidak setuju (STS) dan poin 5 menyatakan sangat setuju (SS) dengan pernyataan yang diajukan dalam kuesioner. Pernyataan dalam kuesioner pada penelitian ini diadopsi dari penelitian Abbas et al. (2020).

Variabel dependen pada penelitian ini adalah perilaku keuangan. Pengukuran pertanyaan variabel dependen tersebut menggunakan Skala Likert 5 poin, poin 1 menyatakan sangat tidak setuju (STS) dan poin 5 menyatakan sangat setuju (SS) dengan pernyataan yang diajukan dalam kuesioner. Semakin tinggi poin responden dalam merespon pernyataan kuesioner mengindikasikan bahwa perilaku keuangan responden semakin baik. Pernyataan dalam kuesioner pada penelitian ini diadopsi dari penelitian Abbas et al. (2020).

Variabel dependen pada penelitian ini adalah perilaku keuangan. Pengukuran pertanyaan variabel dependen tersebut menggunakan Skala Likert 5 poin, poin 1 menyatakan sangat tidak setuju (STS) dan poin 5 menyatakan sangat setuju (SS) dengan pernyataan yang diajukan dalam kuesioner. Semakin tinggi poin responden dalam merespon pernyataan kuesioner mengindikasikan bahwa perilaku keuangan responden semakin baik. Pernyataan dalam kuesioner pada penelitian ini diadopsi dari penelitian Abbas et al. (2020).

Variabel moderasi pada penelitian ini adalah literasi keuangan. Pengukuran pertanyaan variabel moderasi tersebut menggunakan Skala dikotomis yaitu yang menyatakan dua pilihan jawaban benar dan salah dalam pernyataan yang diajukan di kuesioner. Pernyataan dalam kuesioner terdapat dalam Table 1.

\section{Populasi dan Sampel}

Populasi pada penelitian ini adalah seluruh anggota organisasi Muhammadiyah di Indonesia. Sampel yang dipilih adalah responden yang memiliki keanggotaan organisasi 
Muhammadiyah karena dianggap memiliki pengetahuan yang lebih baik mengenai masalah tertentu, terutama dalam bidang keagamaan. Teknik pengambilan sampel menggunakan convenience sampling. Convenience sampling yaitu teknik sampling yang ditujukan bagi siapa saja yang dapat memberikan informasi baik secara tidak sengaja atau kebetulan bertemu dengan peneliti, dapat digunakan sebagai sampel, bila dilihat orang yang memberikan informasiinformasi tersebut cocok sebagai sumber data (Sekaran, 2017)

\section{Teknik Analisis}

Metode analisis pada penelitian ini menggunakan statistik deskriptif, uji instrumen penelitian (uji validitas dan uji reliabilitas), uji asumsi klasik (uji heteroskedastisitas, uji normalitas, dan uji linearitas), uji hipotesis (koefisien determinasi, dan uji statistic t). Pengujian hipotesis menggunakan analisis regresi linier sederhana untuk menguji hipotesis pengaruh langsung. Sedangkan untuk menguji hipotesis moderasi menggunakan Moderated Regression Analysis. Alat bantu yang digunakan untuk analisis menggunakan software statistik SPSS.

\section{HASIL DAN PEMBAHASAN}

\section{Analisis Demografi}

Hasil analisis demografi penelitian menunjukkan bahwa usia tertinggi responden yaitu 55 tahun, usia terendah responden yaitu 20 tahun, dan rata-rata usia responden yaitu 31 tahun. Pekerjaan terbanyak responden pada penelitian ini yaitu tenaga pengajar dengan prosentase $46.08 \%$, terbanyak kedua yaitu tenaga pendidikan dengan prosentase $36.27 \%$, dan terbanyak ketiga yaitu tenaga kesehatan dengan prosentase 17.65\%. Asal AUM responden pada penelitian ini sebagian besar berasal dari Jawa dengan prosentase $81.37 \%$.

\section{[Table 2 about here]}

\section{Statistik Deskriptif}

Jumlah data responden yang diolah pada penelitian ini yaitu 102 data untuk masing-masing variabel. Variabel Financial Behaviour memiliki nilai minimum sebesar 8, maksimum sebesar 20, rata-rata sebesar 15.26 , dan deviasi standar sebesar 2.329. Variabel Locus of Control memiliki nilai minimum sebesar 14 , maksimum sebesar 27 , rata-rata sebesar 21.05, dan deviasi standar sebesar 2.329.

\section{[Table 3 about here]}

Variabel Sikap Keuangan memiliki nilai minimum sebesar 8, maksimum sebesar 20, rata-rata sebesar 15.67, dan deviasi standar sebesar 2.475. Variabel Pendapatan memiliki nilai minimum sebesar 2, maksimum sebesar 10 , rata-rata sebesar 6.94, dan deviasi standar sebesar 1.934. Variabel Religiusitas memiliki nilai minimum sebesar 15, maksimum sebesar 25, rata-rata sebesar 21.14, dan deviasi standar sebesar 2.425. Variabel Literasi Keuangan memiliki nilai minimum sebesar 6, maksimum sebesar 11, rata-rata sebesar 9.85, dan deviasi standar sebesar 1.246.

\section{Pengujian Instrumen}

Uji Instrumen Penelitian pada penelitian ini menggunakan dua uji yaitu uji validitas dan uji reliabilitas. Uji validitas mengukur instrumen penelitian (kuesioner) sudah tepat atau belum. Pengujian validitas pada penelitian ini menggunakan Pearson Correlation, Sugiyono (2013) menyatakan bahwa jika nilai Pearson Correlation diatas 0.3 maka item tersebut valid.

\section{[Table 4 about here]}

Uji instrument penelitian yang kedua yaitu uji reliabilitas. Uji reliabilitas digunakan untuk melihat konsistensi instrumen penelitian jika instrument tersebut digunakan berulang, uji reliabilitas pada penelitian ini menggunakan nilai Cronbach's Alpha jika nilai tersebut diatas 0.60 maka instrument adalah reliabel.

\section{[Table 5 about here]}

Berdasarkan table 3 tentang hasil uji validitas seluruh variabel penelitian adalah valid karena nilai Pearson Correlation diatas 0.3. Berdasarkan table 4 tentang hasil uji reliabilitas seluruh variabel penelitian adalah reliabel karena nilai Cronbach's Alpha diatas 0.6.

\section{Uji Asumsi Klasik}

Uji asumsi klasik yang dilakukan dalam penelitian ini adalah uji normalitas yang menggunakan uji Kolmogorov Smirnov, Uji heteroskedastisitas menggunakan uji Glejser, Uji multikolinieritas dengan melihat nilai VIF dan Tolerance serta Uji Autokorelasi dengan melihat nilai durbin Watson.

\section{Normalitas}

Hasil uji normalitas dengan menggunakan uji Kolmogorov Smirnov mendapatkan hasil nilai signifikansi sebesar 0.2 lebih besar dari 0.05 , sehingga data penelitian dikatakan terdistribusi normal.

\section{[Table 6 about here]}

\section{Heterokedastisitas}

Hasil uji heteroskedastisitas dengan menggunakan uji glejser mendapatkan hasil nilai signifikansi semua variabel lebih besar dari 0.05 , sehingga dapat disimpulkan tidak terjadi gejala heterokedastisitas dalam model regresi.

\section{[Table 7 about here]}

\section{Multikolinieritas}

Hasil uji Multikolinearitas dengan melihat nilai tolerance dan VIF SPSS mendapatkan hasil nilai tolerance semua variabel lebih besar dari 0.1 serta nilai VIF lebih kecil dari 10, sehingga dapat disimpulkan tidak terjadi gejala multikolinieritas dalam model regresi.

\section{[Table 8 about here]}

\section{Autokorelasi}

Hasil uji Autokorelasi dengan melihat nilai Durbin-Watson mendapatkan hasil nilai diantara 2, sehingga dapat disimpulkan 
tidak terjadi gejala Autokorelasi dalam model regresi..

\section{[Table 9 about here]}

\section{Uji Moderated Regression Analysis}

Berdasarkan table 10 didapatkan hasil bahwa variabel Locus of control (X1) berpengaruh terhadap financial behaviour. Nilai signifikansi variabel Locus of control terhadap financial behaviour sebesar 0.016. Variabel Locus of control signifikan pada $5 \%$, karena nilai signifikansi $<0.05$ maka H0 ditolak dan H1 diterima. Nilai koefisien variabel Locus of control terhadap financial behaviour sebesar 0.171 . Hal ini berarti Locus of control berpengaruh positif terhadap financial behaviour.

\section{[Table 10 about here]}

Berdasarkan table 10 didapatkan hasil bahwa variabel Sikap keuangan (X2) berpengaruh terhadap financial behaviour. Nilai signifikansi variabel Sikap keuangan terhadap financial behaviour sebesar 0.002. Variabel Sikap keuangan signifikan pada 5\%, karena nilai signifikansi $<0.05$ maka H0 ditolak dan H2a diterima. Nilai koefisien variabel Sikap keuangan terhadap financial behaviour sebesar 0.213. Hal ini berarti Sikap keuangan berpengaruh positif terhadap financial behaviour.

Berdasarkan table 10 didapatkan hasil bahwa hasil interaksi variabel Sikap keuangan $\left(\mathrm{X}_{2}\right)$ dan literasi keuangan terhadap financial behaviour menunjukkan nilai koefisien positif yaitu 1.481 dengan nilai signifikansi 0.040 . Karena nilai signifikansi $<0.05$ maka $\mathrm{H}_{0}$ ditolak dan $\mathrm{H}_{2 \mathrm{~b}}$ diterima. Hal ini berarti literasi keuangan memperkuat pengaruh positif sikap keuangan terhadap financial behaviour.

Berdasarkan table 10 didapatkan hasil bahwa variabel pendapatan $\left(\mathrm{X}_{3}\right)$ berpengaruh terhadap financial behaviour. Nilai signifikansi variabel pendapatan terhadap financial behaviour sebesar 0.016. Variabel pendapatan signifikan pada $5 \%$, karena nilai signifikansi $<0.05$ maka $\mathrm{H}_{0}$ ditolak dan $\mathrm{H}_{3 \mathrm{a}}$ diterima. Nilai koefisien variabel pendapatan terhadap financial behaviour sebesar 0.213 . Hal ini berarti pendapatan berpengaruh positif terhadap financial behaviour

Berdasarkan table 10 didapatkan hasil bahwa hasil interaksi variabel pendapatan (X3) dan literasi keuangan terhadap financial behaviour menunjukkan nilai koefisien positif yaitu 1.103 dengan nilai signifikansi 0.019 . Karena nilai signifikansi $<0.05$ maka $\mathrm{H} 0$ ditolak dan $\mathrm{H} 3 \mathrm{~b}$ diterima. Hal ini berarti literasi keuangan memperkuat pengaruh positif pendapatan terhadap financial behaviour.

Berdasarkan table 10 didapatkan hasil bahwa variabel religiusitas $\left(\mathrm{X}_{4}\right)$ berpengaruh terhadap financial behaviour. Nilai signifikansi variabel religiusitas terhadap financial behaviour sebesar 0.009. Variabel religiusitas signifikan pada $5 \%$, karena nilai signifikansi $<0.05$ maka $\mathrm{H}_{0}$ ditolak dan $\mathrm{H}_{4}$ diterima. Nilai koefisien variabel religiusitas terhadap financial behaviour sebesar 0.181 . Hal ini berarti religiusitas berpengaruh positif terhadap financial behaviour.

\section{Uji Koefisien Determinasi}

Untuk mengukur kemampuan model dalam menerangkan variasi variabel independen digunakan koefisien determinasi. Nilai $\mathrm{R}^{2}$ yang kecil menunjukkan kemampuan variabel independen dalam menjelaskan variasi variabel dependen sangat terbatas. Adapun hasil dari uji koefisien determinasi terlihat pada table 10.Pada table 10 diketahui nilai $\mathrm{R}^{2}$ sebesar 0,668 atau $66,8 \%$. Hal ini berarti $66,8 \%$ variasi variabel dependen yaitu financial behaviour dapat dijelaskan oleh variabel independen.

\section{Pembahasan Hasil Penelitian Pengaruh LOC terhadap financial behaviour pada Organisasi Keagamaan Muhammadiyah di Indonesia}

Locus of control berpengaruh positif terhadap financial behaviour. Berdasarkan Behavioral Finance Theory yang mempelajari bagaimana manusia secara aktual berperilaku dalam sebuah penentuan keuangan yang dipengaruhi oleh faktor psikologi dan locus of control berkaitan dengan faktor tersebut. Locus of control terbagi menjadi dua yaitu internal dan ekternal, locus of control internal berpengaruh positif terhadap financial behaviour karena faktor tersebut mendorong individu untuk meningkatkan kebiasaan menabung dan kebiasaan tersebut merupakan salah satu bentuk financial behaviour (Cobb-Clark, 2016). Locus of control eksternal berpengaruh positif terhadap financial behaviour karena faktor tersebut dipengaruhi oleh faktor lingkungan. Lingkungan kerja di organisasi muhammadiyah mengajarkan hidup hemat seperti mengatur anggaran dan hal tersebut mencerminkan financial behaviour.

\section{Pengaruh sikap keuangan terhadap financial behaviour pada Organisasi Keagamaan Muhammadiyah di Indonesia}

Sikap keuangan berpengaruh positif terhadap financial behaviour. Sohn et al., (2012) menjelaskan bahwa sikap keuangan adalah bagaimana seseorang bersikap terhadap uang, dimana uang dipandang sebagai kebebasan, imbal hasil dari usaha yang dilakukan serta uang dapat dipandang sebagai sumber kejahatan. Hal ini membuat sikap keuangan sangat penting dalam menentukan perilaku keuangan seseorang. Di dalam semua aspek kehidupan, sikap keuangan sangat dibutuhkan oleh setiap individu tidak terkecuali bagi anggota organisasi keagamaan Muhammadiyah di Indonesia. Hal ini dikarenakan sikap keuangan membantu setiap individu untuk menentukan perilaku individu dalam tindakan sehari-harinya terutama dalam masalah keuangan, yaitu pengelolaan keuangan, penganggaran, dan investasi, baik secara individual maupun secara keorganisasian.

\section{Pengaruh sikap keuangan terhadap financial behaviour pada Organisasi Keagamaan Muhammadiyah di Indonesia yang dimoderasi oleh Literasi Keuangan}

Literasi keuangan memperkuat pengaruh positif sikap keuangan terhadap financial behaviour. Dengan kata lain, pengaruh positif sikap keuangan terhadap financial behaviour akan semakin kuat jika literasi keuangan seseorang semakin baik. Seseorang dengan tingkat literasi keuangan yang tinggi akan memiliki pemahaman tentang keuangan semakin baik dalam mengelola keuangan sehingga menunjukkan sikap 
keuangan yang positif dan membentuk yang perilaku keuangan yang positif pula.

\section{Pengaruh Pendapatan terhadap financial behaviour pada Organisasi Keagamaan Muhammadiyah di Indonesia}

Pendapatan berpengaruh positif terhadap financial behaviour, tinggi dan rendahnya pendapatan seseorang memengaruhi juga financial behaviour orang tersebut. Individu yang memiliki pendapatan lebih tinggi akan lebih longgar dalam financial behaviour karena individu tersebut lebih memiliki kesempatan yang lebih luas dalam pengaturan keuangganya. Abbas dkk., (2020) menyatakan bahwa tingginya pendapatan meningkatkan keinginan anggota organisasi Muhammadiyah untuk membelanjakan pendapatan yang diterimanya.

\section{Pengaruh pendapatan terhadap financial behaviour pada Organisasi Keagamaan Muhammadiyah di Indonesia yang dimoderasi oleh Literasi Keuangan}

Literasi keuangan memperkuat pengaruh positif pendapatan terhadap financial behaviour. Dengan kata lain, pengaruh positif pendapatan terhadap financial behaviour akan semakin kuat jika literasi keuangan seseorang semakin baik. Individu yang memiliki literasi keuangan yang baik akan bijak untuk menggunakan pendapatannya, individu tersebut akan mengalokasikan pendapatannya bukan untuk hal-hal yang konsumtif melainkan untuk menabung atau investasi. Hal tersebut membuktikan bahwa literasi keuangan merupakan salah satu faktor yang penting untuk menggambarkan financial behaviour (Delafrooz dan Paim, 2011). Anggota Muhammadiyah yang tidak memiliki literasi keuangan yang baik akan tidak memiliki kontrol keuangan ketika memeroleh pendapatan sehingga menyebabkan terjadinya kegagalan dalam mengelola keuangan

\section{Pengaruh Religiusitas terhadap financial behaviour pada Organisasi Keagamaan Muhammadiyah di Indonesia}

Religiusitas berpengaruh positif terhadap financial behaviour. Relijiusitas menunjukkan seberapa sering individu mengamalkan nilai-nilai keagamaannya sehingga perilaku keuangan individu tersebut akan mengarah pada nilai - nilai keagamaan. Perilaku orang yang beragama cenderung menghindari keputusan keuangan yang berisiko tinggi seperti keputusan untuk berinvestasi pada hal-hal bukan syariah yang berisiko tinggi (Hilary dan Hui (2009); Kashyap dan Iyer (2009)). Hal tersebut membuktikan bahwa relijiusitas membentuk financial behaviour anggota organisasi.

\section{Kesimpulan}

Berdasarkan hasil penelitian maka kesimpulan penelitian ini adalah semua hipotesis yang diajukan terdukung semua secara statistik. Variabel Locus of control, sikap keuangan, pendapatan, dan relijiusitas dapat memrediksi financial behaviour anggota organisasi Muhammadiyah di Indonesia. Variabel moderasi literasi keuangan memperkuat pengaruh sikap keuangan dan pendapatan terhadap financial behaviour. Hasil penelitian berimplikasi bahwa anggota organisasi Muhammadiyah di Indonesia telah memiliki financial behaviour yang baik berdasarkan variabel penelitian yang digunakan pada penelitian ini.

\section{REFERENCES}

Abbas, Djamila, Muhammad Ali, Mursalim Nohong, and Muhammad Sobarsyah. 2020. "Predicting the Financial Behaviour of the Religious Organization Board in Indonesia." Journal of Asian Finance, Economics and Business 7(12): 1159-66.

Ajzen, I. 2005. Attitudes, Personality and Behaviour. New York: Open University Press

Ajzen, I. 1991. The Theory of Planned Behaviour. Organizational Behaviour and Human Decision Processes, 50, 179-211.

Akmal, H., \& Saputra, Y. E. K. A. 2016. Analisis tingkat literasi keuangan. Jebi (Jurnal Ekonomi Dan Bisnis Islam), 1(2), 235-244. http://journal.febi.uinib.ac.id/index.php/jebi/article/view/37

Ali, A. K. 2016. Impact of religiosity on buying behaviour of financial products: a literature review. International Journal of Finance and Banking Research. https://doi.org/10.11648/j. ijfbr.20160201.14

Amanah, E., Rahadian, D. D., \& Iradianty, A. 2016. The Influence of Financial Knowledge, Financial Attitude and ExternalL Locus of Control on Personal Management Behaviour Case Study of Bachelor Degree Student in Telkom University. E-Proceeding of Management, 3(2), 1228-1235.

Ameliawati, M., \& Setiyani, R. 2018. The Influence of Financial Attitude, Financial Socialization, and Financial Experience to Financial Management Behaviour with Financial Literacy as the Mediation Variable. International Conference on Economics, Business and Economic Education 2018, KnE Social Sciences, 811-832

Baker, H. Kent \& John R. Nofsinger, 2010, Behavioural Finance: An Overview, In Behavioural Finance: Investor, Corporations, and Market, Editors H. Kent Baker and John R. Nofsinger, John Wiley \& Sons, Inc. New Jersey, P, 3 21

Britt, S., Cumbie, J. A., \& Bell, M. M. 2013. The influence of locus of control on student financial behaviour. College Student Journal

Bulutoding, L., Habbe, A. H., Parmitasari, R. D. A., Alwi, Z., \& Abdullah, M. W. 2020. Moslem taxpayers' compliance behaviour in Malaysia. International Journal of Advanced Engineering Research and Science. https://doi.org/10.22161/ ijaers.73.35

Chen, H., dan Volpe, R.P. 1998. An Analysis of Personal Financial Literacy Among College Students 7 (2), 107 - 128. JAI Press Inc.

Cobb-Clark, D. A., Kassenboehmer, S. C., \& Sinning, M. G. 2016. Locus of control and savings. Journal of Banking and Finance. https://doi.org/10.1016/j.jbankfin.2016.06.013

Delafrooz, N., \& Paim, L. 2011. Personal saving behaviour among malaysian employees: Socio demographic comparison. International Conference on Social and Humanity.

Dima, B., Dima, S. M., \& Ioan, R. 2021. Remarks on the behaviour of financial market efficiency during the covid-19 pandemic. The case of VIX. Finance Research Letters. https://doi.org/10.1016/j.frl.2021.101967

Falahati, L. 2011. A comparative study in money attitude among university students: A gendered view. Journal of American Science.

Grohmann, A. 2018. Financial literacy and financial behaviour: Evidence from the emerging Asian middle class. Pacific-Basin Finance Journal, 48, 129-143. doi:10.1016/j.pacfin.2018.01.007

Haerani, S., Parmitasari, R. D. A., Aponno, E. H., \& Aunalal, Z. I. 2019. Moderating effects of age on personality, driving behaviour towards driving outcomes. International Journal of Human Rights in Healthcare. https://doi.org/10.1108/ IJHRH-08-2017-0040

Haroon, O., \& Rizvi, S. A. R. 2020. COVID-19: Media coverage and financial markets behaviour-A sectoral inquiry. Journal of Behavioural and $\begin{array}{lll}\text { Experimental } & \text { Finance, } & 27,\end{array}$ https://doi.org/10.1016/j.jbef.2020.100343

Hess, D. 2012. The impact of religiosity on personal financial decisions. 14, 1-13.

Hilary, G., \& Hui, K. W. 2009. Does religion matter in corporate decision making in America? Journal of Financial Economics. https://doi.org/10.1016/j.jfineco.2008.10.001

Hilgert, M.A \& Hogart M. 2003. Household Financial Management: The Connection

between Knowledge and Behaviour. Federal Reserve Bulletin July 2003

Ida, \& Dwinta, C. Y. 2010. Pengaruh locus of control, pengetahuan keuangan, pendapatan terhadap perilaku manajemen keuangan. Journal of Business 
and Accounting.

Kashyap, R., \& Iyer, E. S. 2009. Not everybody wants to save the world. Journal of Financial Services Marketing. https://doi. org/10.1057/fsm.2009.12

Kholid, M. N., Tumewang, Y. K., \& Salsabilla, S. 2020. Understanding students' choice of becoming certified sharia accountant in Indonesia. Journal of Asian Finance, Economics and Business, 7(10), 219-230. https://doi.org/10.13106/ jafeb.2020.vol7.n10.219

Lai, C. W. (2010). How financial attitudes and practices influence the impulsive buying behaviour of college and university students. Social Behaviour and Personality. https://doi. org/10.2224/sbp.2010.38.3.373

Lefcourt, H. 1982. Locus of Control: Current Trends in Theory and Research. Second Edition, Hillsdale, NJ: Lawrence Erlbaum.

Lusardi, A., Mitchell, O. S., \& Curto, V. 2010. Financial literacy among the young. Journal of Consumer Affairs. https://doi. org/10.1111/j.1745 6606.2010.01173.x

McDaniel, S. W. and J. J. Burnett: 1990, 'Consumer Religiosity and Retail Store Evaluative Criteria', Journal of the Academy of Marketing Science 18, $101-112$.

Meghir, C., \& Pistaferri, L. 2011. Earnings, consumption and life cycle choices. In: Handbook of Labor Economics. https://doi. org/10.1016/S01697218(11)02407-5

Mokhtar, N., Sabri, M. F., Soke, C., \& Ho, F. 2020. Financial capability and differences in age and ethnicity. Journal of Asian Finance, Economics and Business, 7(10), 1081-1091. https:// doi.org/10.13106/jafeb.2020.vol7.no10.1081

Nofsinger, J. R. 2001. The impact of public information on investors. Journal of Banking and Finance. https://doi. org/10.1016/S0378-4266(00)00133-3

OJK. 2013. Literasi Keuangan. Retrieved January 4, 2020, from www.ojk.go.id website: https://www.ojk.go.id/id/kanal/edukasi-danperlindungankonsumen/Pages/Literasi-Keuangan.aspx

Perry, V. G., \& Morris, M. D. 2005. Who is in control? the role of self-perception, knowledge, and income in explaining consumer financial behaviour. Journal of Consumer Affairs. https://doi.org/10.1111/j.1745-6606.2005.00016.x

Ramdani, Z., Amri, Andi., Warsihna, Jaka., Garnasih, TR., Juarsa, Eka. 2021 Perilaku Manajemen keuangan karyawan selama pandemic Covid-19 : Sebuah studi awal. Jurnal Ekonomi dan Bisnis. 8(1).

Renneboog, L., \& Spaenjers, C. (2012). Religion and Finance. In Socially Responsible Finance and Investing: Financial Institutions, Corporations, Investors, and Activists. https://doi. org/10.1002/9781118524015.ch8

Rotter, J. B. (1966). Generalized expectancies for internal versus external control of reinforcement. Psychological Monographs. https://doi.org/10.1037/h0092976

Saraswati, Ade Maya dan Arif Widodo Nugroho. (2021). Perencanaan Keuangan dan Pengelolaan Keuangan Generasi Z di Masa Pandemi COVID-19 melalui Penguatan Literasi Keuangan.

Sudarsono, H., Nuri, R., \& Nugrohowati, I. (2020). Determinants of the intention to consume halal food, cosmetics and pharmaceutical products. Journal of Asian Finance, Economics and Business, 7(10), 831-841. https://doi.org/10.13106/ jafeb.2020.vol7.no10.831

Sugiyono. 2013. Metode Penelitian Pendidikan Pendekatan Kuantitatif, Kualitatif, dan R\&D. Bandung: Alfabeta.

Parmitasari, R. D. A., Alwi, Z., \& Sunarti, S. (2018). The influence of spiritual intelligence and hedonism lifestyle on personal financial management of state higher education students in makassar city. Jurnal Minds: Manajemen Ide Dan Inspirasi. (in Indonesian). https://doi.org/10.24252/minds.v

Perry, V. G., \& Morris, M. D. 2005. Who is in control? the role of self-perception, knowledge, and income in explaining consumer financial behaviour. Journal of Consumer Affairs. https://doi.org/10.1111/j.17456606.2005.00016.

R. Nofsinger, J., \& Varma, A. 2014. Pound wise and penny foolish? OTC stock investor behaviour. Review of Behavioural Finance. https://doi.org/10.1108/RBF-12-04-02

Ricciardi, V. 2008. The Psychology of Risk: The Behavioural Finance Perspective. Handbook of Finance. https:/doi. org/10.1002/9780470404324.hof002010

Ricciardi, Victor \& Simon Helen K. 2000. What is Behavioural Finance? Business, Education and Technology Journal Fall, P.1-9.

Sekaran, Uma dan Roger Bougie, 2017, Metode Penelitian untuk Bisnis: Pendekatan Pengembangan-Keahlian, Edisi 6, Cetakan Kedua, Salemba Empat, Jakarta Selatan 12610.

Shefrin, H., \& Statman, M. 2000. Behavioural Portfolio Theory. The Journal of Financial and Quantitative Analysis, 35(2), 127. doi:10.2307/2676187

Sohn, S. H., Joo, S. H., Grable, J. E., Lee, S., \& Kim, M. 2012. Adolescents' financial literacy: The role of financial socialization agents, financial experiences, and money attitudes in shaping financial literacy among South Korean youth. Journal of Adolescence. https://doi.org/10.1016/j. adolescence.2012.02.002

Weaver, G. R. and B. R. Agle: 2002, 'Religiosity and Ethical Behaviour in
Organizations: A Symbolic Interactionist Perspective', Academy of Management Review 27(1), 77-98.

Yap, R. J. C., Komalasari, F., \& Hadiansah, I. (2018). The effect of financial literacy and attitude on financial management behaviour and satisfaction. Bisnis \& Birokrasi Journal. https:// doi.org/10.20476/jbb.v23i3.9175

https://www.ojk.go.id/id/berita-dan-kegiatan/publikasi/Pages/Survei-NasionalLiterasi-dan-Inklusi-Keuangan-2019.aspx, Diakses 28 Mei 2021

http://alvara-strategic.com/peta-citra-ormas-islam-indonesia/ Diakses 28 Mei 2021.

ConflictofInterestStatement:The authorsdeclare that the research wasconducted in the absence of any commercial or financial relationships that could be construed as a potential conflict of interest.

Copyright $(2022$ and. This is an open-access article distributed under the terms of the Creative Commons Attribution License (CC BY). The use, distribution or reproduction in other forums is permitted, provided the original author(s) and the copyrightowner(s) are credited and that the original publication in this journal is cited, in accordance with accepted academic practice. No use, distribution or reproduction is permitted which does not comply with these terms. 


\section{LIST OF TABLES}

1. Daftar Kuesioner.

2. Analisis demografi.

3. Statistik Deskriptif.

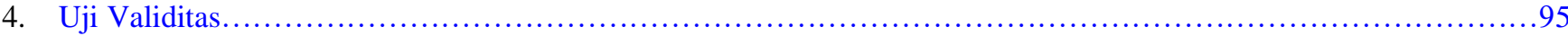

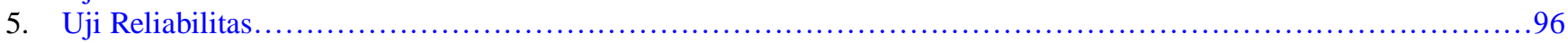

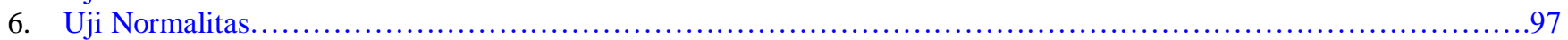

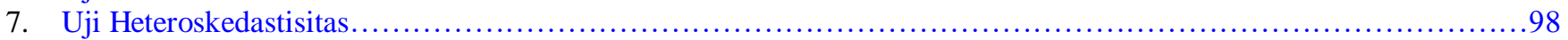

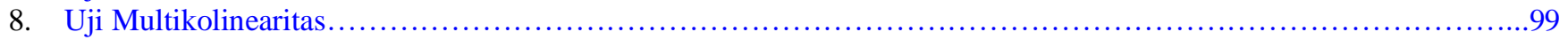

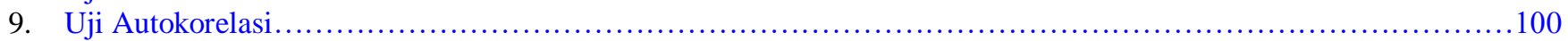

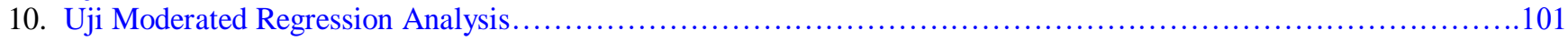


TABLE 1/Daftar Kuesioner

\begin{tabular}{|c|c|c|}
\hline Variabel & Item & Pernyataan \\
\hline \multirow{6}{*}{ LOC } & Loc1 & Saya mampu menyelesaikan masalah pribadi saya \\
\hline & $\operatorname{Loc} 2$ & Saya mampu mengontrol diri saya sendiri \\
\hline & Loc3 & Saya percaya pada diri sendiri \\
\hline & Loc 4 & Saya lebih mudah dipengaruhi oleh lingkungan \\
\hline & Loc5 & Saya tidak berdaya dalam menghadapi masalah hidup \\
\hline & Loc6 & Saya orang yang selalu memiliki inisiatif \\
\hline \multirow{4}{*}{ SIKAP KEUANGAN } & Sike1 & Saya menabung secara rutin dan teratur \\
\hline & Sike2 & Saya selalu memiliki rencana anggaran (budget) \\
\hline & Sike3 & Saya adalah orang yang hemat \\
\hline & Sike4 & Saya bertanggungjawab atas keuangan saya \\
\hline \multirow{2}{*}{ PENDAPATAN } & Pend1 & Saya memiliki sumber penghasilan yang cukup dari upah saya \\
\hline & Pend 2 & Gaji saya adalah sumber penghasilan utama saya \\
\hline \multirow{5}{*}{ RELIGIUSITAS } & Rel1 & Saya benar-benar memahami enam rukun iman dalam Islam \\
\hline & Rel2 & Saya memahami sepenuhnya prinsip-prinsip dasar lainnya dalam Islam \\
\hline & Rel3 & Saya berusaha untuk memenuhi aturan Islam, meskipun sulit \\
\hline & Rel4 & Saya berusaha untuk memenuhi aturan Islam, meskipun mahal \\
\hline & Rel5 & Tujuan hidup saya adalah untuk memenuhi kebutuhan agama \\
\hline \multirow{4}{*}{$\begin{array}{l}\text { FINANCIAL } \\
\text { BEHAVIOUR }\end{array}$} & Fib1 & Saya selalu membayar tagihan tepat waktu (Contoh : membayar listrik, pulsa pascabayar, dll.) \\
\hline & Fib2 & Saya selalu mencatat pengeluaran saya ( baik dalam harian atau bulanan atau tahunan) \\
\hline & Fib3 & Saya memiliki dana tak terduga (dana darurat, emergency fund) \\
\hline & Fib4 & Saya selalu membandingkan harga dipasar sebelum memutuskan untuk melakukan pembelian \\
\hline \multirow{11}{*}{$\begin{array}{l}\text { LITERASI } \\
\text { KEUANGAN }\end{array}$} & Lit1 & $\begin{array}{l}\text { Perbedaan bank konvensional dengan bank syariah adalah bank konvensional menggunakan sistem bunga, sedangkan bank syariah } \\
\text { menggunakan sistem bagi hasil }\end{array}$ \\
\hline & Lit2 & Semua lembaga keuangan (baik bank maupun non bank) dijamin oleh Lembaga Penjamin Simpanan (LPS) \\
\hline & Lit3 & $\begin{array}{l}\text { Fungsi OJK adalah menyelenggarakan sistem pengaturan dan pengawasan yang terintegrasi terhadap keseluruhan kegiatan dalam } \\
\text { sektor jasa keuangan. }\end{array}$ \\
\hline & Lit4 & Salah satu manfaat dari membuat anggaran pribadi yaitu dapat mengontrol setiap pengeluaran pribadi. \\
\hline & Lit5 & Penggunaan kartu kredit yang bijak adalah dengan membayar tagihan secara tepat waktu. \\
\hline & Lit6 & Menyimpan uang di bank merupakan cara menyimpan uang yang aman dan dilakukan setiap kali kita memperoleh pengahasilan. \\
\hline & Lit7 & Perbedaan tabungan dan deposito yaitu deposito untuk investasi, sedangkan tabungan untuk menabung (tabungan biasa). \\
\hline & Lit8 & Salah satu keuntungan yang akan diterima jika berinvestasi saham yaitu dividen \\
\hline & Lit9 & $\begin{array}{l}\text { Berinvestasi saham di sebuah perusahaan, biasanya memberikan keuntungan yang lebih terproteksi dibandingkan membeli unit } \\
\text { reksadana di perusahaan pengelola reksadana. }\end{array}$ \\
\hline & Lit10 & Meminimalisasi risiko kerugian termasuk manfaat asuransi \\
\hline & Lit11 & $\begin{array}{l}\text { Asuransi jiwa merupakan produk asuransi yangmemberikan perlindungan kepada keluarga seandainya suatu saat nanti pemegang } \\
\text { asuransi meninggal. }\end{array}$ \\
\hline
\end{tabular}


TABLE 2 / Analisis Demografi

\begin{tabular}{cl|c|c}
\hline \multicolumn{1}{c|}{ Keterangan } & Nilai & Prosentase \\
\hline Usia & Usia Tertinggi & 55 & 51.9 \\
$-\quad$ Usia Terendah & 20 & 18.86 \\
$-\quad$ Usia Rata-rata & 31 & 29,24 \\
$-\quad$ Tenaga Kesehatan & 18 & 17.65 \\
\hline Pekerjaan & Tenaga Pendidikan & 37 & 36.27 \\
$-\quad$ Tenaga Pengajar & 47 & 46.08 \\
$-\quad$ Jawa & 83 & 81.37 \\
$-\quad$ Sumatera & 8 & 7.84 \\
$-\quad$ Kalimantan & 5 & 4.90 \\
$-\quad$ Sulawesi & 6 & 5.88 \\
\hline
\end{tabular}


TABLE 3 / Statistik Deskriptif

\begin{tabular}{|c|c|c|c|c|c|}
\hline Variabel & $\mathrm{N}$ & Minimum & Maximum & Mean & Std. Deviation \\
\hline Financial Behaviour & 102 & 8 & 20 & 15.26 & 2.329 \\
\hline Locus of Control & 102 & 14 & 27 & 21.05 & 2.191 \\
\hline Sikap Keuangan & 102 & 8 & 20 & 15.67 & 2.475 \\
\hline Pendapatan & 102 & 2 & 10 & 6.94 & 1.934 \\
\hline Religiusitas & 102 & 15 & 25 & 21.14 & 2.425 \\
\hline Literasi Keuangan & 102 & 6 & 11 & 9.85 & 1.246 \\
\hline
\end{tabular}


TABLE 4 / Uji Validitas

\begin{tabular}{|c|c|c|c|c|}
\hline No. & \multirow{4}{*}{ Financial Behaviour } & $\begin{array}{l}\text { Item } \\
\text { yfb1 }\end{array}$ & $\begin{array}{c}\text { Nilai Pearson Correlation } \\
0.546\end{array}$ & $\begin{array}{l}\text { Keterangan } \\
\text { Valid }\end{array}$ \\
\hline \multirow{3}{*}{1.} & & yfb2 & 0.699 & Valid \\
\hline & & yfb3 & 0.758 & Valid \\
\hline & & yfb4 & 0.655 & Valid \\
\hline \multirow{7}{*}{2.} & \multirow{6}{*}{ Locus of Control } & $\mathrm{x} 1 \mathrm{loc} 1$ & 0.607 & Valid \\
\hline & & $\mathrm{x} 1 \mathrm{loc} 2$ & 0.667 & Valid \\
\hline & & x1loc3 & 0.501 & Valid \\
\hline & & x1loc4 & 0.384 & Valid \\
\hline & & $\mathrm{x} 11$ loc5 & 0.311 & Valid \\
\hline & & x1loc6 & 0.432 & Valid \\
\hline & \multirow{4}{*}{ Sikap Keuangan } & $\mathrm{x} 2 \mathrm{sk} 1$ & 0.817 & Valid \\
\hline \multirow{3}{*}{3.} & & $\mathrm{x} 2 \mathrm{sk} 2$ & 0.840 & Valid \\
\hline & & $\mathrm{x} 2 \mathrm{sk} 3$ & 0.751 & Valid \\
\hline & & $\mathrm{x} 2 \mathrm{sk} 4$ & 0.449 & Valid \\
\hline \multirow{3}{*}{4.} & \multirow[t]{3}{*}{ Pendapatan } & $\mathrm{x} 3 \mathrm{pd} 1$ & 0.807 & Valid \\
\hline & & $\mathrm{x} 3 \mathrm{pd} 2$ & 0.888 & Valid \\
\hline & & $\mathrm{x} 4 \mathrm{rg} 1$ & 0.538 & Valid \\
\hline \multirow{4}{*}{5.} & \multirow{3}{*}{ Religiusitas } & $\mathrm{x} 4 \mathrm{rg} 2$ & 0.616 & Valid \\
\hline & & $\mathrm{x} 4 \mathrm{rg} 3$ & 0.701 & Valid \\
\hline & & $\mathrm{x} 4 \mathrm{rg} 4$ & 0.731 & Valid \\
\hline & \multirow{12}{*}{ Literasi Keuangan } & $\mathrm{x} 4 \mathrm{rg} 5$ & 0.704 & Valid \\
\hline \multirow{11}{*}{6.} & & mlk1 & 0.312 & Valid \\
\hline & & mlk2 & 0.438 & Valid \\
\hline & & mlk3 & 0.311 & Valid \\
\hline & & mlk4 & 0.340 & Valid \\
\hline & & mlk5 & 0.407 & Valid \\
\hline & & mlk6 & 0.497 & Valid \\
\hline & & mlk7 & 0.423 & Valid \\
\hline & & mlk8 & 0.316 & Valid \\
\hline & & mlk9 & 0.532 & Valid \\
\hline & & mlk10 & 0.366 & Valid \\
\hline & & mlk11 & 0.441 & Valid \\
\hline
\end{tabular}


TABLE 5 / Uji Reliabilitas

\begin{tabular}{|c|c|c|c|}
\hline No. & Variabel & $\begin{array}{c}\text { Nilai } \\
\text { Cronbach's Alpha }\end{array}$ & Keterangan \\
\hline 1. & Financial Behaviour & 0.672 & Reliabel \\
\hline 2. & Locus of Control & 0.695 & Reliabel \\
\hline 3. & Sikap Keuangan & 0.700 & Reliabel \\
\hline 4. & Pendapatan & 0.603 & Reliabel \\
\hline 5. & Religiusitas & 0.674 & Reliabel \\
\hline 6. & Literasi Keuangan & 0.696 & Reliabel \\
\hline
\end{tabular}


TABLE 6 / Uji Normalitas

\begin{tabular}{|c|c|c|}
\hline \multirow[t]{2}{*}{ Kolmogorov-Smirnov } & $\begin{array}{c}\text { Signifikansi } \\
\text { Asymp. Sig. (2-tailed) }\end{array}$ & \multirow{2}{*}{$\begin{array}{l}\text { Keterangan } \\
\text { Data terdistribusi normal }\end{array}$} \\
\hline & 0.200 & \\
\hline
\end{tabular}


TABLE 7 / Uji Heterokedastisitas

\begin{tabular}{clcc}
\hline No. & \multicolumn{1}{c}{ Variabel } & Signifikansi & Keterangan \\
1. & Locus of Control & 0.995 & \\
2. & Sikap Keuangan & 0.341 & Tidak Terjadi Gejala \\
3. & Pendapatan & 0.772 & Heterokedastisitas \\
4. & Religiusitas & 0.474 & \\
5. & Literasi Keuangan & 0.204 & \\
\hline
\end{tabular}


TABLE 8 / Uji Multikolinieritas

\begin{tabular}{clccc}
\hline \multicolumn{1}{c}{ Variabel } & VIF & Tolerance & Keterangan \\
1. & Locus of Control & 0.852 & 1.174 & Tidak Terjadi Gejala \\
2. & Sikap Keuangan & 0.624 & 1.602 & Multikolinieritas \\
3. & Pendapatan & 0.418 & 2.394 & 1.178 \\
4. & Religiusitas & 0.849 & 1.332 & \\
5. & Literasi Keuangan & 0.751 & & \\
\hline
\end{tabular}


TABLE 9 / Uji Autokorelasi

Nilai Durbin-Watson

Keterangan

Keterangan
Tidak terjadi Autokorelasi 
TABLE 10 / Uji Moderated Regression Analysis

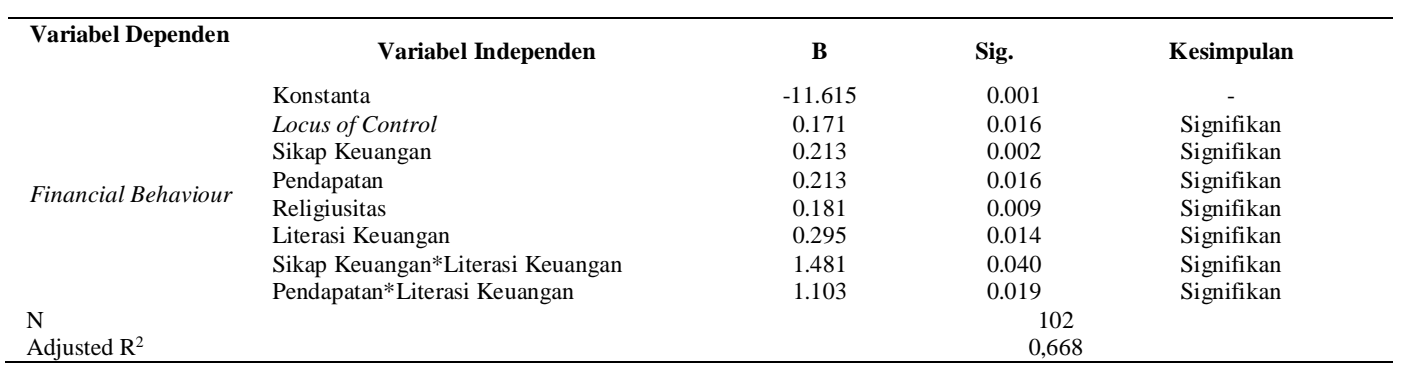

